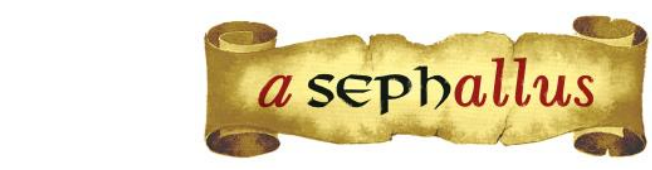

Revista aSEPHallus de Orientação Lacaniana

Núcleo Sephora de Pesquisa sobre o Moderno e o Contemporâneo

ISSN 1809 - 709 X

\title{
Reflexões psicanalíticas sobre o amor a partir de Eros $^{1}$
}

Rebeca Espinosa Cruz Amaral

Mestranda em Teoria Psicanalítica pela Universidade Federal do Rio de Janeiro / UFRJ (Rio de Janeiro, brasil) com

bolsa do CNPQ.

Psicóloga pela Universidade Federal Fluminense / UFF (Niterói, Rio de Janeiro, Brasil) Pós-graduada em Psicanálise, sujeito e Cultura pela Faculdade de Medicina de Campos dos Goytacazes / FMC

(Campos dos Goytacazes, Rio de Janeiro, Brasil).

E-mail: respinosacamaral@hotmail.com

\begin{abstract}
Carlos Alberto Ribeiro Costa
Doutor em Teoria Psicanalítica pela Universidade Federal do Rio de Janeiro / UFRJ (Rio de Janeiro, brasil) Professor do Curso de Graduação em Psicologia da Universidade Federal Fluminense / UFF (Niterói, Rio de Janeiro, Brasil) Professor associado do Programa de Teoria Psicanalítica da Universidade Federal do Rio de Janeiro (Rio de Janeiro, Brasil) e da Universidade Federal Fluminense / UFF (Niterói, Rio de Janeiro, Brasil)

E-mail: carloscosta.psi@gmail.com
\end{abstract}

\begin{abstract}
Resumo: "Eros" é uma das palavras utilizadas pelos gregos para definir o amor, de modo que abordá-la pode ser um caminho para trabalhar a temática amorosa. Isto se confirma ao adentrarmos o campo psicanalítico para pautarmos nossa investigação, pois neste se apresentam importantes referências e alusões a este termo. Por isso, este artigo objetiva apontar algumas articulações entre o amor e o conceito de Eros em meio às reflexões psicanalíticas, o que se justifica pelo paradoxal movimento em que ora Eros parece abarcar o amor, e, ora o amor parece caminhar entre as dimensões pulsionais Eros e Tânatos. Com este objetivo, empregaremos uma revisão bibliográfica de obras da psicanálise e algumas articulações destas à obra $O$ Banquete de Platão. Veremos, então, que a pluralidade semântica, as relações entre amor e falta e a complexidade dos processos afetivos ligados à esfera erótica nos levam a estabelecer certo contraste entre as tradições mítico-filosóficas clássicas e o discurso psicanalítico, pois, se naquelas o direcionamento ao "Bem supremo" e a Unicidade se fazem horizonte e alvo, naquele vemos como que o Um que tensiona o amor não poderia existir se não fosse a falta, mãe de Eros e condição de existência do amor.
\end{abstract}

Palavras-Chave: Amor; Eros; Psicanálise

Réflexions psychanalytiques sur l'amour d'Eros: "Eros" est l'un des mots utilisés par les Grecs pour définir l'amour, donc l'approcher peut être une façon de travailler sur le thème de l'amour. Ceci est confirmé en entrant dans le champ psychanalytique pour guider notre enquête, car il présente d'importantes références et allusions à ce terme. Cet article vise donc à mettre en évidence certaines articulations entre l'amour et le concept d'Eros au milieu de réflexions psychanalytiques, ce que justifie le mouvement paradoxal dans lequel parfois Eros semble embrasser l'amour, et parfois l'amour semble marcher entre des dimensions. Pulsions Eros et Thanatos. À cette fin, nous utiliserons une révision bibliographique d'œuvres de psychanalyse et quelques articulations de celles-ci avec l'œuvre Le Banquet Platon. Nous verrons donc que la pluralité sémantique, les relations entre amour et manque et la complexité des processus affectifs liés à la sphère érotique nous amènent à établir un certain contraste entre les traditions mytho-philosophiques classiques et le discours psychanalytique, puisque Le «Bien suprême» et I'Unité deviennent horizon et cible, en ce sens que Celui qui raffermit l'amour ne peut exister s'il n'est pas dépourvu de manque, mère d'Eros et condition d'existence de l'amour.

Mots-Clés: L'amour; Eros;

Psychoanalytic reflections of love from Eros: "Eros" is one of the words used by the Greeks to define love, so approaching it can be a way of working on the love theme. This is confirmed by entering the psychoanalytic field to guide our investigation, as it presents important references and allusions to this term. Therefore, this article aims to point out some articulations between love and the concept of Eros in the midst of psychoanalytic reflections, which is justified by the paradoxical movement in which sometimes Eros seems to embrace love, and sometimes love seems to walk between dimensions. Eros and Thanatos pulses. For this purpose, we will use a bibliographical revision of works of psychoanalysis and some articulations of these to the work The Plato Banquet. 
We will see, then, that semantic plurality, the relations between love and lack and the complexity of affective processes linked to the erotic sphere lead us to draw a certain contrast between the classic mythical-philosophical traditions and psychoanalytic discourse, since if in them the direction towards "Supreme Good" and Oneness become horizon and target, in that we see that the One who tenses love cannot exist if it were not lack, mother of Eros and condition of existence of love.

Key words: Love; Eros; Psychoanalysis 


\section{Reflexões psicanalíticas sobre o amor a partir de Eros}

Rebeca Espinosa Cruz Amaral \& Carlos Alberto Ribeiro Costa

\section{Introdução}

No que concerne à civilização ocidental, parece impossível falar do amor sem nos referirmos a "Eros", uma das palavras utilizadas pelos gregos para defini-lo. Tal impossibilidade se faz mais premente visto nossa abordagem pautar-se na teoria psicanalítica que, criada por Freud, apresenta, desde os textos deste, importantes referências e alusões a este termo.

Tendo isso em vista, o objetivo do presente artigo é de, em meio às reflexões psicanalíticas sobre o amor, recortar alguns pontos em que estas se articulam ao conceito de Eros. Tal propósito se justifica, segundo pensamos, a partir da problemática de um duplo e paradoxal movimento nas teorizações: por vezes Eros parece abarcar o amor, e, por outras, o amor parece caminhar entre Eros e Tânatos, dimensões pulsionais em constante fusão e desfusão. Além disso, naquilo em que amor e Eros se aproximam, vemos a constante relação destes com a falta, índice crucial para que o amor, em sua vertente neurótica, exista e perdure.

Com este objetivo, então, o artigo empregará como metodologia a revisão bibliográfica de obras da psicanálise, principalmente das postulações de Freud e as releituras destas operadas por Lacan, bem como de algumas articulações destas reflexões à obra de Platão (1991), uma das matrizes dos discursos sobre Eros em nossa cultura.

Começaremos, portanto, numa tentativa de conceituar o amor - tentativa sempre um pouco fracassada, uma vez que consiste em tentar abordar pela palavra aquilo que, como veremos, contém em si um impossível de dizer. Para tal, buscaremos tecer semelhanças e diferenças entre o amor e alguns conceitos centrais da psicanálise dos quais este se aproxima, e, neste percurso, observaremos a ideia das possíveis articulações entre amor e falta. Em seguida, aludiremos à história de Eros - este que é considerado o Deus do amor - cujo mito também nos desvela articulações à falta.

Dando prosseguimento, veremos como a noção de Eros é articulada ao amor de diferentes formas nos vários momentos de elaboração, nas obras de Freud e Lacan. E, por fim, traremos mais algumas considerações a respeito da obra platônica - que já terá estado presente ao longo de todo trabalho, mas que cuja riqueza aqui não se esgota - para mostrar como, principalmente no que concerne a esta articulação do amor com a falta, dentre outras postulações, as colocações desse texto continuam a ter ressonâncias atuais, sempre lançando luz sobre os impasses das relações amorosas de alguma forma.

\section{O Amor em Freud: entre sexual, libido e desejo.}

Propor uma reflexão - qualquer que seja - sobre o amor para a psicanálise, nos faz questionar inicialmente se poderíamos tratá-lo conferindo-lhe o status de um conceito. Neste sentido, é importante começar destacando que não há em Freud - nem em Lacan, cujas contribuições são imprescindíveis para nós - um trabalho específico sobre o amor que reúna teorizações a respeito do mesmo, como sua definição, constituição, importância e consequências para os sujeitos ${ }^{2}$. Porém, 
diversos são os textos que circulam esse tema, de modo que o amor está, pois, presente no seio de diversos conceitos centrais da obra psicanalítica como - citando alguns dos postulados por Freud Pulsão (Freud, 1915/1996), Narcisismo (Freud, 1914/1996), Complexo de Édipo (Freud, 1924b/1996), Castração (Freud, 1905/1996), Ideal do eu/Supereu (Freud, 1923/1996), dentre outros - bem como no avançar da obra lacaniana. Em relação a esta última, é importante dizer, desde já, que Borges e Abramovich (2011) destacam que ao contrário de outras noções que foram objeto das construções teóricas deste autor, o amor não é alçado ao estatuto de conceito fundamental. Estas autoras afirmam que Lacan recorre a estratégias surpreendentes para falar sobre o amor, fazendo suas elucubrações através da literatura, da poesia, dos mitos e das artes em geral, e, com isso, proferindo ditos, adjetivações e fórmulas que passam como aforismos. Entretanto, tais adjetivações acabam por nos atordoar, pois são compostas de "ditos carregados de ambiguidade, fórmulas enigmáticas, semidizeres que cortam qualquer possibilidade de um pensamento unívoco quanto ao amor" (Borges e Abramovich, 2011, p. 8).

Feita esta ressalva, ao iniciarmos nosso percurso pela obra Freudiana, podemos observar que, num primeiro momento, Freud colocou o amor e a sexualidade de forma indiferenciada, utilizando o primeiro destes termos por vezes como sinônimo de libido e até de desejo, de modo que é só com o tempo que o amor ganha contornos conceituais mais nítidos. Em relação à sexualidade, porém, Freud (1905/1996) explicita, no prefácio que faz à quarta edição de seus Três ensaios sobre a teoria da sexualidade que a psicanálise é responsável por uma ampliação do conceito de sexualidade, aproximando-se essa do conceito de Eros trabalhado por Platão em $O$ Banquete. Tal aproximação, todavia, também não se tratará de uma equivalência, de modo que o amor está atrelado à sexualidade, mas não é um sinônimo desta.

No que concerne à sexualidade, podemos, então, destacar as postulações de Elia (1995) que, seguindo as teorizações de Freud e se opondo à concepção que a reduz a uma função individual e reprodutora, a considera - a partir das elaborações freudianas referentes ao inconsciente ${ }^{3}$ - como atrelada ao campo do pulsional. Neste, por não haver um objeto específico, a satisfação pulsional não pode ser toda, e sendo apenas parcialmente satisfeita por estrutura é que ela é infinitamente relançada em busca de satisfação. Nesse sentido, o autor afirma que a psicanálise trata do sexual enquanto "estrutural e necessariamente parcial, e o ato mesmo de sua enunciação conclama a postulação do para além do sexual" (Elia, 1995, p. 53). Em relação a isso, acrescenta que há um para além da sexualidade e do princípio de prazer, que chamamos de pulsões de morte - das quais falaremos mais a seguir -, as quais nos colocam diante do fato de que, portanto, de diversas maneiras, a relação sexual é não-toda.

Algo dessa impossibilidade retorna, inclusive, nas conceituações freudianas que atestam que a sexualidade é sempre infantil, em virtude de não sermos capazes de abandonar totalmente posições de satisfação anteriormente atingidas, motivo pelo qual as repetimos e reeditamos indefinidamente. Neste sentido, segundo Elia (1995), ela articula-se ao inconsciente em uma organização fálica, pois 
para ela não há uma representação psíquica da diferença anatômica entre os sexos, apenas um registro das consequências de tais diferenças, de modo que a organização inconsciente não faz correspondência à duplicidade genital, não se representando nele os dois órgãos genitais, mas sim o falo, como algo que pode faltar. Assim, o falo introduz a dimensão simbólica da castração e assinala a incompletude radical e estrutural do sujeito em relação ao sexo, inscrevendo a ordem do sexual definitivamente no registro da parcialidade. Afirma, então que

Esta sexualidade, dita infantil, é marcada pelo impossível da relação sexual, a relação complementar entre os sexos, e é a sexualidade do sujeito humano: o adulto não terá outra, não encontrará a complementaridade sexual, sua sexualidade é infantil. [...] se todo encontro do sujeito com o real de sua experiência sexual só pode ser significado depois, precisamente porque foi marcado, no momento mesmo desse encontro, pelo significante que, por não representar a totalidade da experiência constitui o real do sexo; se enfim, há sempre um segundo tempo que, para o sujeito, é o primeiro de seu saber, devemos então pensar o infantil em psicanálise como algo da ordem de um inacessível à experiência imediata (impensável para a fenomenologia husserliana), como algo inconsciente. Deduz-se, deste ponto, que a realidade do inconsciente seja sexual. (Elia, 1995, p. 75)

Dito isto, é importante ainda voltarmos às diferenciações e articulações entre os conceitos acima citados para trazer brevemente o conceito de libido, tendo em vista que o mesmo, por vezes, também é confundido com as concepções a respeito do amor. Temos, portanto, que nos remeter a Freud (1923[1922]/1996), que define a libido como "um termo empregado na teoria dos instintos para descrever a manifestação dinâmica da sexualidade" (Freud, 1923[1922]/1996, p. 265). Apesar desta definição estar posta apenas em 1923[1922]/1996, é interessante dizer que já em 1905/1996, Freud chega a uma primeira teoria da libido, a qual afirma ser uma força com caráter qualitativo, mas também quantitativamente variável e que pode medir os processos da excitação sexual. Separa essa libido em libido do ego, ou libido narcísica, e libido de objeto, que ao fixar-se neles ou abandoná-los, norteia o indivíduo na atividade sexual que o levará à satisfação, ou seja, à extinção parcial e temporária de tal libido.

Compreendidas as definições que cercam os conceitos de sexualidade e libido, faz-se necessário acrescentarmos ainda algumas postulações referentes à relação entre o amor e o desejo, tendo em vista que, segundo Lacan (1972-1973/2008), ambos dizem da relação do sujeito com sua falta, sendo diferentes respostas para esta.

Assim, em relação ao desejo, com base na leitura de Freud e Lacan, vemos ser a experiência de satisfação que está em sua base, na medida em que o processo se dá da seguinte forma: Quando nasce, o bebê é tomado por uma série de estímulos internos e constantes, como, por exemplo, a fome, que the causam um mal-estar por gerarem um acúmulo de tensão, de excitação. A esse malestar o bebê reage com o grito e diante deste não-sentido do grito, o Outro - aqui encarnado pela mãe, sendo uma ordem que não é plena, consistente, mas sim furada e que traz a marca do 
significante e do desejo - o interpretará como uma demanda, um pedido, fornecendo-Ihe o alimento e com isso suprimindo sua tensão e causando nele a vivência e o registro de sua primeira experiência de satisfação.

Com isso, ficam associados a essa experiência a imagem do objeto que proporcionou a satisfação (o seio) e a do movimento que a permitiu (a sucção), de modo que ao despertar novamente a necessidade essas imagens serão reinvestidas na tentativa de reviver a situação de satisfação original, o que, segundo Freud já havia postulado em 1895, em seu Projeto para uma psicologia científica (Freud, 1950[1895]/1996), é causado por um impulso que podemos chamar de desejo. Porém, ao reproduzir alucinatoriamente essa experiência, nos deparamos com o desapontamento pela ausência do objeto real (o seio), sem o qual a necessidade persiste e não há satisfação, sendo a única saída acionar a imagem do movimento, chupando o vazio num movimento que produz satisfação da zona erógena e faz com que a sensação de prazer vá se desvinculando da satisfação da necessidade, inaugurando a pulsão sexual e o desejo, que por sua vez, tenta sempre restituir a situação dessa primeira experiência.

Mas, Lacan (1957-1958/1999) afirma que esta demanda passa a não visar somente o objeto da necessidade, como por exemplo, o leite, mas também se dirige ao Outro e se refere a algo que não às satisfações que clama, sendo uma demanda de uma presença ou de uma ausência, o que pode ser visto na relação primordial com a mãe, de modo que ele postula que

a demanda, no fundo, é uma demanda de amor - demanda daquilo que não é nada, nenhuma satisfação particular, demanda do que o sujeito introduz por sua simples e pura resposta à demanda (Lacan, 1957-1958/1999, p. 394).

Segundo Elia (2004), porém, esta demanda, que é sempre de amor, só pode ser entendida articulada ao objeto faltoso que a habita, o qual, tendo sido fragmentado e descaracterizado pela passagem do significante, é nomeado por Lacan como objeto $a$. E este objeto $a$, que sempre habita o objeto em geral, é também entendido como objeto causa do desejo - e não objeto do desejo -, ou seja, que por faltar na experiência, causa o desejo do sujeito.

Se a demanda elevou, por assim dizer, o objeto à categoria de Outro, e lhe deu todas as prerrogativas de presença e de amor, o desejo faz o movimento contrário, reconduz o movimento da demanda ao plano do objeto, rebaixa o Outro a esse plano, destitui o Outro das prerrogativas que a demanda lhe conferiu e dá novamente os títulos de honra ao objeto. O desejo degrada o Outro em objeto, ou seja, reduz seu grau, promovendo uma queda do Outro e sua virada no objeto que, dele caindo, o descompleta, o fura, o barra. (Elia, 2004, p. 55)

É por isso que Elia (2004) afirma não ser possível conceber a demanda sem a intervenção do desejo, pois há na primeira uma mentira estrutural que torna impossível sua satisfação plena, visto que ela promove o desprendimento dos objetos ao articular as necessidades do sujeito pela 
linguagem. Em sua verdadeira estrutura, portanto, ela já é desde sempre habitada pelo desejo que marca para ela a impossibilidade de satisfação.

A partir disto, em relação ao desejo, diz Lacan (1958/1998) que este não é nem o apetite da satisfação e nem a demanda de amor, mas sim o fenômeno da fenda que resulta da subtração do primeiro à segunda. Deste modo, Lacan (1960-1961/2010), ao tentar aludir à origem do amor, o faz articulando-o ao desejo, na medida em que para ele o amor advém na tentativa de recobrir a vacilação da demanda que surge articulada a estrutura desejante. Afirma ele:

Ora, é à questão formulada ao Outro, quanto ao que ele pode nos dar e ao que tem para nos responder, que se liga o amor como tal. Não que o amor seja idêntico a cada uma das demandas com as quais o assediamos, mas ele se situa no mais além dessa demanda, na medida em que o Outro possa ou não nos responder como última presença (Lacan, 19601961/2010, p. 215).

Este Outro, que ele define como lugar terceiro, lugar da fala, que sempre está presente nas relações com o pequeno outro semelhante a partir da articulação significante, é, segundo ele, um Outro incessantemente evanescente, e que por este motivo, nos coloca também na posição de incessantemente evanescentes. Diante disso, e a partir de sua postulação de que o desejo é sempre o desejo do Outro, é na medida em que este Outro é evanescente, que se dá a mola do nascimento do amor, pois é por haver falta nesta estrutura desejante, neste Outro, que se estabelece um mais-além que faz com que seja demandado dele uma resposta sobre a falta. Acrescenta, assim, que

o amor é aquilo que se passa nesse objeto em direção ao qual estendemos a mão pelo nosso próprio desejo e que, no momento em que nosso desejo faz eclodir seu incêndio, nos deixa aparecer, por um instante, essa resposta, essa outra mão que se estende para nós, bem como seu desejo (Lacan, 1960-1961/2010, p. 225).

Mas aqui, é importante acrescentar que este estender as mãos do outro é um movimento imaginário, pois essa resposta ele a dá não sabendo a seu respeito, como diz Lacan (19561957/1995) no Seminário 4, no sentido de que amar é dar aquilo que não se tem.

Deste modo, Lacan (1960-1961/2010) coloca que a princípio o sujeito não ama, ele demanda amor, é passivo - como, por exemplo, na relação primordial da criança com a mãe - transformando-se em amante, ou como diz Lacan, passando de érômeno à érastès pela operação do que ele chama de metáfora de amor. Diz assim, que para ele

é no próprio princípio da situação que o sujeito é introduzido como digno de interesse e de amor, érômenos. É para ele que se está ali. Este é o efeito - se podemos dizer manifesto. Mas existe um efeito latente, que está ligado à sua não-ciência, a sua insciência. Insciência de quê? - daquilo que é justamente o objeto de seu desejo de um modo latente, quero dizer, objetivo, ou estrutural. Esse objeto já está no Outro, e é na medida em que é assim que ele é, quer o saiba, quer não, virtualmente constituído como érastès. Simplesmente 
por esse fato ele preenche essa condição de metáfora, a substituição pelo érastès do érôménos, que constitui em si mesmo o fenômeno do amor (Lacan, 1960-1961/2010, p. 244).

Ou seja, Lacan (1960-1961/2010) nos mostra que a metáfora amante/amado que constitui o fenômeno do amor vem tentar responder ao enigma do que quer o Outro, de modo que o falo imaginário (agalma) vem recobrir algo de uma falta entre sujeito e outro, produzindo um sentido, ou, podemos dizer, um objeto imaginário como atingível. O caminho que aqui estamos trilhando, porém, é o que elucida a passagem da metáfora enquanto simbolização e referência ao Outro àquilo que se dirige ao limite da simbolização, do reconhecimento pelo outro, e da cópula.

Com isso, avançando na obra lacaniana, notamos que é nessa perseguição narcísica pela completude que o encontro amoroso revela, na verdade, a falta no Outro, é um encontro faltoso, convocando o sujeito à sua condição desejante. Isto deixa claro o caráter plural do amor na psicanálise, e nos faz reafirmar que na tentativa de dizer algo sobre este que contém em si um indizível, só podemos contorná-lo. Deste modo, ao falar do amor devemos nos referenciar a essa pluralidade presente ao longo do desenvolvimento da obra de Freud, e, posteriormente de Lacan, nas quais ele é entendido como ligado ao narcisismo (Freud, 1914/1996; Lacan, 1949/1998), à idealização (Freud, 1921/1996; Lacan, 1953-1954/2009), à castração e ao Complexo de Édipo (Freud, 1924b/1996), como fator de constituição dos sujeitos e das civilizações (Freud, 1930[1929]/1996), como dom (Lacan, 1956-1957/1995), falsidade (Lacan, 1964/2008), uma negação (Lacan, 1966), um monstro ou importuno (Lacan, 1967), um melaço (Lacan, 1968/2008), uma máscara (Lacan, 1971/2009), suplência (Lacan, 1972-1973/2008), ligado à poesia (Lacan, 1976/1977), dentre outros.

Abordar essas diversas teorizações, porém, não é aqui nosso objetivo, sendo-o, como já dissemos, versar sobre suas articulações ao conceito de Eros, de modo que não é sem propósito que finalizamos este tópico com essa indicação do amor como uma possível resposta a falta, pois isto nos leva a um dos possíveis modos de olhá-lo em sua articulação a Eros.

Acreditamos ter sido importante destacar isso, porém, ainda pelo fato de que tanto a pluralidade de sentidos do amor, como sua relação a falta, concerne também, guardadas as devidas diferenças, às matrizes culturais míticas da subjetivação deste sentimento em nossa civilização. É o que veremos agora, no tópico seguinte, num contraponto entre essa perspectiva e a perspectiva psicanalítica.

\section{Eros: Filho da falta}

Como é nosso objetivo demonstrar neste trabalho, em nossa cultura parece incontornável falar do amor sem nos referirmos a Eros, e, de fato, esta é uma das palavras utilizadas pelos gregos para defini-lo. Todavia, há, também, uma pluralidade de significados para "amor" na língua grega, que acaba por valer-se, centralmente, de três palavras para referir-se a ele, cada uma enfatizando uma diferente dimensão do amor. Assim, temos, dizendo de maneira resumida, segundo o Dicionário de mitologia grega e romana (Schmidt, 1995): "Ágape", como um amor mais ligado ao divino, ao 
incondicional, e isento de conotação sexual; "Philia" ou "Philos", referindo-se a um amor fraternal; e, "Eros", entendido como o amor erótico, associado ao desejo e à atração física.

Para que, então, possamos lançar luz sobre algumas dessas articulações entre Eros, o amor e a psicanálise, nos valeremos, inicialmente, de alguns pontos centrais da história dessa última nomeação, como apontados por Schmidt (1995), que podem auxiliar-nos.

Primeiramente, é importante dizer que Eros é considerado na mitologia grega como o deus do amor e do desejo, ou do erotismo. Uma das primeiras referências a ele aparece em Teogonia, livro do poeta Hesíodo que data aproximadamente do século 8a.C, onde ao versar sobre o surgimento do mundo a partir da história dos deuses, nos traz Eros como filho do Caos - vazio primitivo, original do universo -, motivo pelo qual ele é considerado como uma força ordenadora, unificadora. É também deste modo que ele é apresentado por Empédocles, filósofo que viveu entre 495 e 444 a.C, e o compreendia como poder que unia os elementos fazendo-os passar do caos ao cosmos.

Posteriormente, porém, ele passou a ser conhecido como filho de Afrodite e Zeus. Sendo um deus do Olimpo e detentor de uma grande beleza, atirava flechas em direção a deuses e mortais geralmente atendendo pedidos de sua mãe - para que estes se apaixonassem. Além disso, nessa versão, Eros é representado na maioria das vezes como uma criança, visto que conta-se que ele era muito mimado por Afrodite, a qual chegou a queixar-se de seu aspecto sempre infantil - o que, vale dizer, mudou após o nascimento de seu irmão, quando Eros tornou-se um homem muito belo. Apesar disto, alguns outros autores alegam que Afrodite teria apenas o adotado, o que recoloca em questão sua filiação.

Temos, então, Platão, que em O Banquete (Platão, 1991), ao qual já aqui nos referimos, o define como filho de Póros (o Expediente) - que realiza a delimitação dos espaços, que ilumina a escuridão e abre caminho para o sol - e Pênia (a Pobreza, a Falta), os quais teriam se envolvido no dia da festa pelo nascimento de Afrodite e o gerado - motivo pelo qual, inclusive, entende-se que Afrodite o tornara seu protegido. Logo, Eros é filho da Falta - o que o associa com uma imagem de busca constante e perpétua insatisfação -, mas também do caminho.

Caminho da falta, uma falta a caminho, a falta que abre um caminho. Mas também um caminho falto de procedimentos, caminho sem essência... (...) O amor como caminho que não leva a parte alguma... senão à visão imediata, totalidade dissipada. Nós gostaríamos, pois do que não temos: o objeto (de amor) é o objeto que falta (Kristeva, 1988, p. 95).

Aqui, vale acrescentar que a filiação de Eros nos permite ainda notar sua associação ao desejo, pois ele é o filho feito pela Pobreza somente na medida em que ela toma para si algo do Expediente. Ela, que segundo conta o mito estava do lado de fora do banquete dos deuses em comemoração à Afrodite mendigando as sobras da festa, vê Póros que, embriagado pelo néctar, saiu da festa e dominado pela embriaguez adormeceu nos jardins. É, então, que vendo-o inconsciente ela deita-se ao seu lado e concebe Eros, pegando dele o que deseja, o falo, o agalma, de modo que podemos dizer também de Eros ser ele fruto de uma satisfação fálica. Filho amado de um momento 
(mítico) de realização de um desejo, passa a vida a oscilar entre miséria e opulência, na busca pela sonhada (e inalcançável) completude que um dia o constituiu.

Não é totalmente desconectado disto, portanto, que também no texto platônico citado acima, a origem do amor é atribuída ao mito do Andrógino, segundo o qual o amor surge na tentativa de recuperar uma unidade, completude supostamente existente nos seres antes de um corte que os dividiu. Tal concepção traremos um pouco mais detidamente adiante - tendo sido aqui trazida apenas a título de ilustração - pois antes é preciso que retomemos ainda algumas considerações a respeito da história do deus Eros.

Sobre isto, portanto, Kristeva (1988) mostra que Eros tem também na obra platônica a significação de uma elevação alada rumo ao Supremo, ou seja, é responsável por um movimento ascendente da alma que, decaída, recorda-se de já ter voado mais alto. Assim, em Eros o desejo do que falta é aspiração à união com o Supremo Bem e, com isso, à imortalidade, onde o corpo do outro - um belo jovem - é considerado apenas como um intermediário interprete e sintetizador chamado a preencher um vazio para constituir uma unidade total de onde a alma será transportada por Eros para mais perto de sua unificação com o divino, com a perfeição.

São tais postulações que bem retratam o mito de Eros (o amor) e Psiquê (a alma). Neste, Eros é incumbido por Afrodite a lançar uma flecha em Psiquê - uma princesa, mortal, de estonteante beleza que despertou a inveja de Afrodite - que a enredaria em uma paixão com uma criatura monstruosa. Porém, Eros acaba se apaixonando e casando-se com ela, impondo a condição, entretanto, que ela nunca veja seu rosto. Mas, em uma noite, aproveitando-se do sono de Eros, Psiquê aproxima sua vela do mesmo e vê a beleza de seu rosto, momento em que ela fica tão extasiada que não vê cair uma gota de cera no amado, o qual acorda e, sentindo-se traído pela esposa, rompe suas relações com a mesma. Após um tempo, porém, em que ambos padecem de um grande sofrimento - chegando Psiquê a aproximar-se da morte - Eros implora a Zeus e, com a sua concessão, Psiquê torna-se uma deusa imortal e passa a habitar o Olimpo. Curioso destacar que, segundo conta o mito, do amor entre Eros e Psiquê nasceu Hedonê (ou Volúpia), a deusa do prazer. Assim, a imortalidade de Psiquê só é conseguida por meio de Eros, o que demonstra que na mitologia e num certo tipo de discurso filosófico, alma e amor são indissociáveis.

Não é, porém só na mitologia e no discurso filosófico que alma e amor mostram-se ligados, mas também na psicanálise. Em 1960-1961/2010, por exemplo, Lacan desenvolve algumas considerações em relação à alma - enquanto certa promessa de um belo futuro - a partir da análise de um quadro do pintor Zucchi chamado Psiche sorprende Amore. Em sua leitura deste, ele afirma que Psiquê só surge como alma na medida em que o desejo que a cumulou escapa, se esquiva e dela foge. Ele encontra, assim, entre o complexo de castração e a alma um centro comum, ponto de cruzamento - não harmonia - e entende a posse de uma alma como modo de guardar o símbolo fálico. Após esta data, porém, Lacan fica alguns anos sem articular estes termos, o que faz 
novamente em 1973/2008 ao renomear o amor de um modo que o liga à alma, chamando-o, então, de "almor".

Neste momento, a alma é por ele compreendida como o que permite que o ser falante suporte 0 intolerável do mundo, o que a faz ser ali suposta estranha, fantasmática. Além disso, sua existência é também questionada e reconhecida como um possível efeito do amor. Ela é vista, assim, como possível, mas não necessária. É tendo tudo isso em vista, que Allouch (2010) afirma que apesar de Lacan não formular desta forma, "o almor é um nome do amor redutor do ser" (ALLOUCH, 2010, p. 380), ou seja, ele prolonga e dá certa consistência à exigência de um amor acostumado com o paraser, que se endereça do semblante ao semblante, onde a alma é, pois, um disfarce, um hábito que veste o corpo como uma imitação barata.

Vemos, assim, que seja como filho de Poros e Pênia, ou seja relacionado a alma, Eros está sempre atrelado a uma falta, sempre marcado por uma impossibilidade que esta faz existir. E não é de outro amor, que não de Eros, que Platão (1991) fala em O Banquete, termo o qual, Freud retoma na psicanálise, como veremos adiante.

\section{Eros na psicanálise: Da expansão da sexualidade ao segundo dualismo pulsional}

Neste momento, faz-se importante, retomarmos algumas colocações freudianas a respeito de Eros. Inicialmente, como já dissemos, ele o aproxima da ampliação do conceito de sexualidade que opera com a psicanálise. Faz isso no texto Os Três Ensaios sobre a Teoria da Sexualidade (Freud, 1905/1996) - considerado um dos mais importantes e também mais polêmicos dentre seus textos que é divido em três capítulos - As aberrações sexuais; A sexualidade infantil; e As transformações da puberdade - e versa essencialmente sobre as descobertas feitas por ele até então a respeito do papel central da sexualidade na constituição dos sujeitos e sua importância na causação das neuroses, bem como abre questões que serão posteriormente trabalhadas pelo autor ao longo de sua obra. É, portanto, neste momento, que o próprio Freud (1905/1996) deixa claro, já no prefácio que faz à quarta edição, que a psicanálise é responsável por uma ampliação do conceito de sexualidade ${ }^{4}$, aproximando-se essa do conceito de Eros trabalhado por Platão (1991) em O Banquete. Vale destacar, no entanto, que essa "aproximação freudiana", não obstante, não faz coincidir, mas reitera uma série de tensões e diferenças com relação ao discurso filosófico. Uma delas, por exemplo, consiste no fato apontado por Miller (1989) de que enquanto no discurso filosófico Eros é visto de maneira divinizante - ou seja, como um Deus, como trouxemos acima - a psicanálise não o aborda desta forma. Segundo o autor, ao tomar Eros, Freud não aborda um Deus, mas o articula a um elemento na teoria das pulsões, como veremos.

Após então, este primeiro momento de sua teoria em que o aproxima da sexualidade, Freud, passa longos anos sem se referir diretamente a Eros, até que o retoma ao formular seu segundo dualismo pulsional. É neste que Freud (1920/1996) une e transforma o que até então entendíamos como pulsões do eu e pulsões sexuais em Eros - enquanto libido das mesmas que procura unir as 
substâncias vivas - e especula que Eros opera desde o princípio da vida, aparecendo, portanto, como uma pulsão de vida que se opõe a uma pulsão de morte - Tânatos - criada a partir da animação da substância inorgânica e que visa retornar ao estado inanimado.

É válido destacar que ao unir em Eros as pulsões do eu e as pulsões sexuais, ele está unindo o amor e a fome - pois que é desta forma que ele se refere aos componentes de seu primeiro dualismo em $1914 / 1996^{5}$ - e internalizando-os neste conceito único que passa a nomear como pulsões de vida - ou, como aqui estamos nos referindo, Eros -, bem como está novamente articulando amor e sexualidade. Assim, Eros e amor não são exatos sinônimos, mas o amor está em Eros contido, é uma de suas partes, assim como está a sexualidade em jogo nele.

Diante de tudo isto, Lacan (1972-1973/2008) afirma que a concepção freudiana do amor o aborda de certa forma pela perspectiva do fazer Um, tomando Eros como uma tensão rumo ao um. É neste sentido, que ele se questiona "Eros, será ele tensão para o Um?" (Lacan, 1972-1973/2008, p. 13). Vemos, porém, que já nesta pergunta ele já coloca a palavra a qual temos que nos deter, pois que Eros é a tensão ao Um, não sua realização.

Queremos apenas acrescentar, então, que é diante disso que Lacan (1975) retoma suas postulações sobre o gozo do Outro para concluir, então, que

Esse gozo do Outro, todos sabem a que ponto é impossível, e mesmo contrariamente ao mito que Freud evoca, a saber, que o Eros, isso seria fazer um, justamente é isso que mata a gente, é que em nenhum caso dois corpos podem fazer um, por mais que se apertem; não cheguei a ponto de colocá-lo no meu texto, mas tudo o que se pode fazer de melhor nesses famosos enlaces é dizer "me aperte forte!", mas não se aperta tão forte que o outro acabe morrendo disso. De forma que não há nenhuma espécie de redução ao um. É a mais formidável piada (Lacan, 1975).

Importante destacar aqui, que esse objetivo de "a partir de dois fazer um" denota, como mostra Lacan na citação acima um certo caráter letal do amor. Neste ponto é importante retomarmos alguns pontos que já citamos anteriormente e a partir dele avançarmos para versarmos sobre o que está em jogo na relação entre o amor e a morte.

\section{Amor entre Eros e Tânatos}

Em 1930[1929]/1996, Freud já postulava uma relação de agressividade para com o outro ao dizer que ao visar unir os membros da sociedade de maneira libidinal, além dos sacrifícios exigidos à satisfação sexual, na forma de certa restrição a essa, a civilização exige também modificações no que concerne a inclinação à agressividade, inerente ao homem, segundo o autor. Vale destacar que essa hostilidade se dá a partir da própria constituição dos sujeitos, como postulado por Freud (1915/1996) ao afirmar que nesse processo há uma passagem inicial de um "ego da realidade" original para um "ego do prazer", o qual divide o mundo externo numa parte que lhe é agradável, e que incorpora a si, 
e num remanescente estranho de modo a isolar uma parte de seu próprio eu e projetá-la no mundo externo sentindo-a como hostil.

Assim, segundo Freud (1930[1929]/1996), os homens enxergam os outros como ajudantes para o trabalho e objetos sexuais, mas também como outro que pode ser objeto de sua agressividade satisfazendo-a. Este, porém, segundo ele, é o maior impedimento à civilização, e por este motivo, afirma ele, o processo civilizatório se coloca a serviço de Eros, na medida em que seu propósito é unir indivíduos libidinalmente. Conclui, assim, que a evolução da civilização nada mais é do que a representação entre a luta de Eros e da Pulsão de Morte - do qual a pulsão agressiva é o principal derivado. Ou seja, é a costura de laços que possibilita o controle ao ímpeto de nossa agressividade na medida em que a missão da libido é tornar inócua a pulsão destruidora (FREUD, 1924a/1996).

É tendo isso em vista que muitos autores se referem a Eros como o que pode fazer frente à destruição, tendo, assim, certa função de proteção em relação à Tânatos, uma proteção do sexual em relação ao real de onde o amor é visto como proteção à morte, algo que vem em suplência à inexistência. Porém, há aí um paradoxo referente ao osso do erotismo, pois como mostra Freud em 1930[1929]/1996, aquilo que nos protege do mal-estar, ao mesmo tempo é também fonte de um mal-estar.

Disto também fala o poeta Octávio Paz, em seu livro A dupla chama: Amor e Erotismo (Paz, 1994), onde afirma que o erotismo possui uma dupla face: fascinação diante da vida e diante da morte. Deste modo, para o autor, na metáfora erótica prazer e morte estão sempre presentes, pois que Tânatos é a sombra de Eros e, aqui, a sexualidade é tanto resposta à morte, como apresenta uma faceta onde o prazer é morte - afirmação diante da qual Freud corrigiria dizendo que há um além do prazer que é a morte, o que Lacan nomeará por gozo. É assim, que também de maneira dupla ele fala de certo ritmo do erotismo, composto por separação e regresso, este como uma volta à natureza reconciliada, a um Grande Todo como um lugar de origem onde morte e vida se abraçam. Paz (1994) acrescenta que o amor é temporal, o que faz dele simultaneamente tentativa de fazer de um instante, eternidade, e, consciência da morte. Para ele, "o amor não vence a morte, mas a integra na vida" (Paz, 1994, p. 130), o que nos faz concluir que não há, então, amor sem mal-estar.

Assim, não é sem conter de alguma forma essa dimensão da morte - esse caráter letal, como afirmamos acima - que o amor com ela se relaciona, pois que nas postulações de Freud (1930 [1929]/1996), este já deixava claro que mesmo a evolução da civilização sendo a representação entre a luta de Eros e Tânatos, uma pulsão inexiste sem a outra, pois elas estão em constante movimento de "fusionamento" e "desfusionamento", são intricadas de modo que Eros, então, banha-se sempre nas águas de Tânatos.

Não é à toa, por exemplo, que ao fazer suas considerações sobre O Banquete, Lacan (19601961/2010) demonstra que nos casos em que a metáfora do amor é realizada, ou seja, onde o érômeno advém como érastès, essa realização só advém na morte, motivo pelo qual esta metáfora não convém. A fusão, portanto, mata o amor, e, é neste sentido que Bauman (1997) - sociólogo e 
leitor da psicanálise - afirma que "O ideal do amor é seu túmulo e o amor só chega lá como um cadáver. É como se Tânatos conduzisse a carruagem de Eros" (Bauman, 1997, p. 118).

E ainda, no final do Seminário 20 - onde está em destaque a dimensão real - ao aproximar amor e morte Lacan (1971-1972/2012) demonstra como o amor se reúne à morte no que ela tem de mais destrutivo e como essa conjunção é inerente à paixão na medida em que visa-se ter o ser do parceiro, mesmo que isso ocasione a destruição desse ser.

É diante de tudo isto que Fortes (1999) afirma ser o amor um solo profícuo para o surgimento da violência onde a fusão devoradora na qual dois rumam em direção a transformam-se em um desdobra-se em uma potência de ódio na relação amorosa frente à perda de si, dos limites referenciais do eu a partir dos quais não há mais a oposição entre sujeito e objeto. Isso nos remete, pois, a presença intrínseca do ódio ao sentimento amoroso, que Freud já destacava ao postular a ambivalência como característica fundamental do amor, na medida em que o ódio está presente neste como marca inapagável. Isto também porque, não podemos esquecer que o ódio como relação de objeto é, como afirma Freud (1915/1996), mais antigo que o amor, provindo da recusa originária do mundo exterior pelo eu narcísico, de modo que ele permanece sempre em relação com as pulsões. Assim, quando a integridade do eu é inflamada pela ligação entre a força do desejo e o amor, o ódio emerge do recalcado.

Vale destacar que, também em 1915/1996, Freud postulou o par amor-ódio como uma pulsão - ou ainda, como um dos três pares pulsionais de que trata neste texto - onde a inversão do amor em ódio é para ele um exemplo de uma inversão do conteúdo pulsional - uma das vicissitudes pulsionais. A Lacan, porém, isto não convém muito, visto que este distancia de certa forma o amor e também o ódio, portanto - do âmbito da pulsão, afirmando serem estes - assim como a ignorância - paixões do ser.

Em relação a isto, Dunker (2017) afirma que o ódio possui uma função erótica e lê a postulação de Lacan de que o ódio se encontra na interseção entre o imaginário e o real afirmando que o ódio é um "sinal de que reconhecemos a presença de um fragmento de real que atravessa a estrutura de ficção na qual o amor se desenvolve" (Dunker, 2017, p. 74).

Neste sentido, é importante dizer que Lacan (1972-1973/2008), ao falar da abordagem do ser pela via do amor fala a respeito de um verdadeiro amor - ou, "uma verdadeira amor" $^{\text {"6 }}$-, assim considerado por sua relação com o ódio, pois neste momento ele afirma que não se conhece nenhum amor sem ódio e que a verdadeira amor desemboca no ódio. É, então, em sequência a isto que ainda neste seminário ele formula o neologismo do "amódio" - que será melhor explorado dois anos depois -, através do qual demonstra que enquanto se ama supõe-se um saber sobre o desejo, quando se odeia supõe-se um não saber.

Não entraremos a fundo nas formulações lacanianas a respeito do amódio. Mas é importante destacar que a partir deste momento Lacan passa a articulá-los indissociavelmente, frisando que sendo amódio o nome de uma relação com o outro - que não é nem amor e nem ódio, mas onde 
estes servem de veículo a ele -, esta relação está para além do bem e do mal, ela trata do real em jogo. Este real, segundo ele, coloca um certo limite ao amor, limite que caracteriza e é próprio do amódio.

Em relação a esta questão do limite, é valido dizer, portanto, que a figura - podemos dizer inédita - do amor trazida pela psicanálise carrega em si um caráter limitado, com o qual, porém, sabe jogar. No que concerne a esta limitação interna do amor, Allouch (2010) - grande leitor da obra lacaniana que dedica um de seus livros a temática do amor - esclarece que ela não é devida a nenhum traço específico, mas simplesmente à sua própria realização, que é limitada e impossível em sua totalidade. Assim, ele define esse jogo que o amor deve saber jogar - e que é o jogo do amor da seguinte forma:

Uma palavra bem simples, poderia abordar esse jogo: amar é deixar o outro ser único. Efetivamente único e mesmo assim amado. Esse amor não unifica, não fabrica "um", a despeito de desagradar a alma de Aristófanes; ele também não permite "estar a dois". Então, o que acontece com o amado? Ele é amado, mas nem por isso com um amor que atacaria sua não menos preciosa solidão. Amado, ele poderá sentir-se não amado. Não amado, ele poderá sentir-se amado. $\mathrm{O}$ que se deixa abreviar assim: ele terá obtido o amor que não se obtém (Allouch, 2010, p. 12-13).

É importante dizer que estas últimas postulações citadas - em relação ao amódio, aos limites do amor e ao seu jogo - se encontram nos últimos seminários de Lacan - posteriores ao Seminário 20: Mais, ainda -, relacionadas às formulações deste autor sobre o nó borromeano, nas quais aqui não adentraremos em função do recorte e dos limites deste trabalho.

Agora, então, para finalizar, nos debruçaremos ainda mais uma derradeira vez sobre o banquete que nos serve Platão. Isto, pois acreditamos que a leitura desta exímia obra pode auxiliarnos também - para além das considerações a respeito de uma (im)possível teoria do amor - em reflexões extremamente necessárias à nossa clínica a respeito das relações amorosas em seus impasses.

\section{Um banquete atual: Leitura do impasse nas relações amorosas}

Assim, é da obra O Banquete (Platão, 1991), diálogo platônico escrito por volta de 380a.C.e constituído por diálogos sobre a natureza e as qualidades de Eros, entendido pelos envolvidos como um dos tipos do amor, que queremos trazer ainda alguns últimos recortes que nos mostram como muito daquilo que ele demonstra, é de suma importância pra nossas discussões atuais sobre o amor, à luz da psicanálise. Não é à toa que, ao dedicar um seminário à temática da transferência, Lacan (1960-1961/2010) retoma suas teorizações sobre o amor e, para versar sobre este tema, recorre a esta célebre obra de Platão (1991), por localizá-la historicamente na origem de uma explicação sobre o amor em nossa cultura, bem como do desenvolvimento deste que é, segundo ele, a mais profunda, radical e misteriosa relação entre os sujeitos. Assim, sua escolha desta obra se dá por sua crença de 
que ela oculta em si algo de radical em relação à mola do amor, seu objeto de estudo na época, da qual já falamos anteriormente. E ainda, também não é à toa que em quase todos os itens trabalhados por este artigo a alguma referência a alguma das postulações deste texto.

Nosso interesse, portanto em retornar a este momento, é pelo fato de que ao vasculhar a obra de Platão em busca do que chamou de a natureza do amor, Lacan (1960-1961/2010) deu um destaque especial à última cena que se desenrola entre Sócrates e Alcibíades, por esta trazer não só o tema do agalma, que será usado por Lacan como base de sua conceituação do objeto $a$, como também revelar uma estrutura que pode ser articulada, segundo Lacan, com a posição do desejo. A partir, então, do destaque dado ao agalma, ele afirma que o motivo pelo qual o objeto apaixona é por haver escondido nele o objeto do desejo, o agalma, que acaba por causar um decaimento do Outro da demanda de amor em objeto do desejo ${ }^{7}$, o que coloca o amor, segundo conclui Allouch (2010) em via de ser absorvido pelo desejo, mas também, em via de englobá-lo.

No que concerne a esta relação, Ferreira (2005) esclarece que

Diante da estrutura do desejo, nenhuma significação e nenhum parceiro podem suturar o hiato que, sob a forma de falta, não cessa de comparecer. O homem inventou o amor para negar sua natureza excêntrica e transfigurar esse objeto do desejo (objeto a) em agalma (i[a]) [...] mergulhamos na ilusão de que o amor pode suturar o corte sem costura da operação significante [...] ilusão tecida letra a letra por uma esperança fálica (Ferreira, 2005, p. 24).

Tal postulação faz-nos recordar ainda da fala de Aristófanes neste mesmo texto - rememorada até mesmo por Freud $(1905 / 1996)^{8}$ - onde este afirma que inicialmente havia três gêneros na humanidade, o masculino, o feminino e o andrógino - este sendo um gênero distinto - e que cada um destes possuía uma forma inteiriça, de modo que primariamente éramos uma unidade, seres completos. Tais seres, porém, por sua grande força e vigor, iniciaram um embate com os deuses ao tentarem escalar ao céu, despertando, com isso, a fúria destes deuses. Estes, então, como forma de castigo, resolveram fazê-los mais fracos cortando-os em dois, motivo pelo qual, desde então, cada um de nós vive a buscar o outro que possa nos fazer recuperar tal unidade e completude.

Diante disso, Ferreira (2005) afirma que é a um mito que Aristófanes recorre para definir o amor como a procura do todo, cura diante da mutilação, onde amante e amado desejam apenas confundirem-se em um só ser, condição que outrora haviam vivido, mas que havia sido perdida. Segundo ela, "assim nasceu o amor, "restaurador da nossa antiga natureza, em sua tentativa de fazer um só de dois e de curar a natureza humana"'" (Ferreira, 2005, p. 111). Amar torna-se, com isso, segundo a autora, sinônimo de um desejo de ao unir-se, confundir-se com o amado.

Com isso, podemos dizer que o amor, via idealização e supervalorização - como postulado por Freud (1921/1996) -, se confirmaria como um tempo de suspensão do impossível da relação sexual, postulado por Lacan (1972-1973/2008). Porém, o que não podemos perder de vista é que ao nos referirmos ao discurso de Aristófanes, sabemos que este traz uma história que é da ordem de um 
mito. Lacan (1960-1961/2010) define os mitos como o que se relaciona com o inexplicável do real, acrescentando que o que quer que se responda ao desejo é sempre inexplicável.

Ferreira (2005) destaca a partir disto que o mito é um discurso - apresenta uma articulação significante - que nos permite visualizar o simbólico a serviço de uma produção imaginária na tentativa de dar conta de algo impossível, real. E, diante disso, afirma que "tanto a esfera, como a harmonia originária, quanto o amor, como tendência à unificação, só podem ser pensados no universo mítico" (Ferreira, 2005, p. 116), de modo que a crença nessas construções tenta retirar de cena o impossível da relação sexual.

Esta mesma autora, porém, antes mesmo de postular diretamente o amor como um mito, já havia afirmado que ao esperar do amor que ele efetuasse a junção de dois seres em um só, esperava-se na verdade um milagre, pois, o que falta no amante - o objeto de desejo - e faz com que ele busque um amado, este também não o terá, de modo que o amor não elimina a falta, inerente à constituição do sujeito. Assim, "o destino do homem é ser desejante e amar na lógica do não-todo" (Ferreira, 2004, p. 11).

É diante disso, portanto, que podemos ver que o amor não erradica a falta inerente ao campo sexual, motivo pelo qual, neste sentido, ele é uma ilusão, como diz Lacan (1972-1973/2008). Afinal, esta aspiração de fazer Um é vã diante do impossível da parceria amorosa - repercussão do impossível da relação sexual onde o amor só faz semblante.

Neste sentido, podemos afirmar que o amor vem em suplência à inexistência da relação sexual, como afirma Lacan (1972-1973/2008), mas não para fazê-la existir, de modo que o restabelecimento de uma suposta unidade é da ordem do impossível, pois, embora ainda hoje acreditemos no amor enquanto uma busca pela completude, em seu cerne o sujeito se depara sempre com um encontro faltoso, motivo pelo qual no encontro amoroso há sempre um impasse.

E, de certa forma, felizmente há este impasse, pois a plena satisfação, o encontro de uma resposta exitosa e da suposta unidade perdida, teria como consequência o fim do amor, do que concluímos que é, portanto, somente como encontro faltoso, onde está implicado o desejo que o amor pode continuar existindo. O impasse, assim, não permite que amor e desejo cessem, não permite, portanto, que nos aproximemos, sem mediação, de Tânatos, mas que permaneçamos próximos a Eros, este que é o filho da falta.

\section{Considerações Finais}

Neste momento de chegada de nosso trabalho - que outorgou, a si, o ofício de pensar a complexidade das relações entre amor e Eros no interior das obras psicanalíticas de Freud e Lacan -, mister se faz retomarmos, brevemente, um pouco daquilo que pudemos encontrar no decorrer de nosso processo de pesquisa e escrita.

Num primeiro momento, pudemos interrogar como as noções de amor e Eros foram sendo dialeticamente (re)construídas a partir das elucubrações freudianas acerca das noções de sexualidade, 
libido e desejo. Sobressaiu-se, para nós, a importância da dimensão pulsional do amor que, ao operar por sua lógica parcial, interroga as fantasias de unicidade ligadas aos ideais românticos coetâneos a Freud. Tal parcialidade se atualizou de forma pujante, segundo apreendemos, em Lacan, para quem as diferenças entre demanda, necessidade e desejo denotam a falta como algo que permite conjugar, psicanaliticamente, amor e Eros.

A pluralidade semântica, as relações entre amor e falta e a complexidade dos processos afetivos ligados à esfera erótica nos levaram a estabelecer certo contraste entre as tradições mítico-filosóficas clássicas e o discurso psicanalítico: se naquelas o direcionamento ao "Bem supremo" e a Unicidade se fazem horizonte e alvo, naquele vemos como o Um que tensiona o amor não pode existir se não fosse a falta, mãe de Eros e condição de existência do amor. Nas relações entre Eros e Psiquê (a "alma"), Lacan frisa a dimensão do encontro no desencontro, ao cunhar o neologismo "almor" como insígnia disso que estando junto, resiste em se fazer Um.

Por fim, o recurso aos desdobramentos posteriores da obra freudiana, permitiu recolher, por outro lado, algumas das relações entre amor e ódio, como articulação possível entre os fusionamentos e desfusionamentos entre Eros - pulsões de vida - e Tânatos - pulsões de morte. Eros mostra-se, logo, a partir de sua relação com a falta e a não totalização, como um dos recursos ante o fenecimento do campo das tensões vitais, presente nas faces mortíferas do amor.

\section{Notas}

1. Este artigo baseia-se na dissertação de mestrado de Rebeca Espinosa Cruz Amaral, em desenvolvimento no Programa de Pós-Graduação em Teoria Psicanalítica da Universidade Federal do Rio de Janeiro (UFRJ), orientada pelo Prof. Dr. Carlos Alberto Ribeiro Costa, momentaneamente intitulada "Onde o amor toca o real: idealização, impossível e invenção em um estudo sobre o(s) amor(es) na psicanálise".

2. Sendo uma possível exceção apenas os três trabalhos que posteriormente ele reuniu sob o título de Contribuições à Psicologia do Amor I, II e III, quais sejam: Um tipo especial de escolha de objeto feita pelos homens (FREUD, 1910/1996), Sobre a tendência universal a depreciação na esfera do amor (FREUD, 1912a/1996) e O tabu da virgindade (FREUD, 1918[1917]/1996).

3. Sobre isto, Conté (1995) afirma que a sexualidade se revela como campo onde "algo se furta irredutivelmente ao sujeito em seu esforço de se realizar, e o marca com uma não-realização, uma falha, um limite, que devem ser reconhecidos como constitutivos da própria subjetividade" (CONTÉ, 1995, p. 77). Isto, pois, esta falha é, segundo ele, o que Freud descobriu e designou como o inconsciente, na medida em que no campo da sexualidade o sujeito só se constitui enquanto marcado por um não-saber sobre o que, no interior deste campo, ele é. 
4. Em 1917[1916-17]/1996, Freud esclarece que com as perversões e a sexualidade infantil a psicanálise ampliou o conceito do sexual para além do genital e da finalidade da reprodução.

5. "Existem vários pontos a favor da hipótese de ter havido desde o início uma separação entre os instintos sexuais e os outros instintos do ego [...] em primeiro lugar, a distinção feita nesse conceito corresponde à distinção popular comum entre a fome e o amor." (FREUD, 1914/1996, p. 85-86).

6. O que demonstra sua relação com a feminização, da qual aqui não trataremos diretamente, mas que é válido destacar, na medida em que - dentre outras articulações - a posição feminina está relacionada a um saber fazer com a falta que também deve estar implicado no amor, uma vez que ele pretende dar conta de um vazio.

7. Para melhor esclarecer este ponto é válido trazer aqui duas citações, a primeira do próprio Lacan (1960-1961/2010), e a segunda de uma leitura realizada por Allouch (2010), assim: "o mais chocante, o último recurso do desejo, esse algo que sempre obriga mais ou menos o amor a dissimulá-lo, é que sua visada é a queda do Outro maiúsculo, em outro a, minúsculo" (LACAN, 1960-1961/2010, p. 222) e "desejar é [...] renunciar a esse falo, seu decaimento sendo precisamente o que dá acesso ao objeto do desejo, ao pequeno a" (ALLOUCH, 2010, p. 203).

8. "A teoria popular sobre a pulsão sexual tem seu mais belo equivalente na fábula poética da divisão do ser humano em duas metades - homem e mulher - que aspiram a unir-se de novo no amor" (FREUD, 1905, p. 129).

\section{Referências Bibliográficas}

Allouch, J. (2010). Amor Lacan. 1. ed. Rio de Janeiro: Companhia de Freud.

Bauman, Z. (1997). Ética pós-moderna. Tradução de João Rezende Costa. São Paulo: Paulus.

Borges, S.; Abramovich, S. (2011). O amor e suas letras. Rio de Janeiro: 7letras.

Dunker, C. (2017). Reinvenção da intimidade - políticas do sofrimento cotidiano. São Paulo: Ubu Editora.

Elia, L. (1995). Corpo e sexualidade em Freud e Lacan. Rio de Janeiro: Uapê.

Elia, L. (2004). O conceito de sujeito. Rio de Janeiro: Zahar. (Passo-a-passo;38)

Ferreira, N. P. (2004). A teoria do amor na psicanálise. Rio de Janeiro: Zahar. (Passo-a-passo;38)

Ferreira, N. P. (2005). Amor, ódio e ignorância: literatura e psicanálise. Rio de Janeiro: Rios Ambiciosos.

Fortes, I. (1999). No amor: Ser um ou ser dois? In Tempo Psicanalítico: Revista da Sociedade de Psicanálise Iracy Doyle. v. 31, Rio de Janeiro. p. 121-128.

Freud, S. (1996). Três ensaios sobre a teoria da sexualidade. In J. Salomão (Trad.) Edição standard brasileira das obras psicológicas completas de Sigmund Freud (V. 7, pp.119-231). Rio de Janeiro: Imago. (Trabalho original publicado em 1905) 
Freud, S. (1996). Sobre o narcisismo: Uma introdução. In J. Salomão (Trad.) Edição standard brasileira das obras psicológicas completas de Sigmund Freud (V. 14, pp. 77-108). Rio de Janeiro: Imago. (Trabalho publicado em 1914)

Freud, S. (1996). Os instintos e suas vicissitudes. In J. Salomão (Trad.) Edição standard brasileira das obras psicológicas completas de Sigmund Freud (V. 14, pp. 123-144). Rio de Janeiro: Imago. (Trabalho original publicado em 1915)

Freud, S. (1996). Além do Princípio do Prazer. In J. Salomão (Trad.) Edição standard brasileira das obras psicológicas completas de Sigmund Freud (V. 18, pp. 17-72). Rio de Janeiro: Imago. (Trabalho original publicado em 1920)

Freud, S. (1996). Psicologia de grupo e análise do ego. In J. Salomão (Trad.) Edição standard brasileira das obras psicológicas completas de Sigmund Freud (V. 18, pp. 75-146). Rio de Janeiro: Imago. (Trabalho original publicado em 1921)

Freud, S. (1996). Dois verbetes de enciclopédia. In J. Salomão (Trad.) Edição standard brasileira das obras psicológicas completas de Sigmund Freud (V. 18, pp. 265-268). Rio de Janeiro: Imago. (Trabalho original publicado em 1923[1922]).

Freud, S. (1996). O ego e o id. In J. Salomão (Trad.) Edição standard brasileira das obras psicológicas completas de Sigmund Freud (V. 19, pp. 13-82). Rio de Janeiro: Imago. (Trabalho original publicado em 1923)

Freud, S. (1996). O problema econômico do masoquismo. In J. Salomão (Trad.) Edição standard brasileira das obras psicológicas completas de Sigmund Freud (V. 19, pp. 179-190). Rio de Janeiro: Imago. (Trabalho original publicado em 1924a)

Freud, S. (1996). A dissolução do complexo de Édipo. In J. Salomão (Trad.) Edição standard brasileira das obras psicológicas completas de Sigmund Freud (V. 19, pp. 195-201). Rio de Janeiro: Imago. (Trabalho publicado em 1924b)

Freud, S. (1996). O mal-estar na civilização. In J. Salomão (Trad.) Edição standard brasileira das obras psicológicas completas de Sigmund Freud (V. 21, pp. 27-148). Rio de Janeiro: Imago. (Trabalho original publicado em 1930[1929]).

Freud, S. (1996). Projeto para uma psicologia cientifica. In J. Salomão (Trad.) Edição standard brasileira das obras psicológicas completas de Sigmund Freud (V. 1, pp. 355-166). Rio de Janeiro: Imago. (Trabalho original publicado em 1950[1895]).

Kristeva, J. (1988). Histórias de amor. Rio de Janeiro: Paz e Terra.

Lacan, J. (1998). O estádio do espelho como formador da função do eu. In Escritos. (pp. 96-103). Rio de Janeiro: Jorge Zahar. (Trabalho original publicado em 1949).

Lacan, J. (2009) O Seminário livro 1: os escritos técnicos de Freud. 2. ed. Rio de Janeiro: Jorge Zahar, 2009. (Trabalho original publicado em 1953-1954).

Lacan, J. (1995). O Seminário livro 4: a relação de objeto. Rio de Janeiro: Jorge Zahar. (Trabalho original publicado em 1956-1957). 
Lacan, J. (1999). O Seminário livro 5: as formações do inconsciente. Rio de Janeiro: Jorge Zahar. (Trabalho original publicado em 1957-1958).

Lacan, J. (1998). A significação do falo. In Escritos. (pp. 692-703). Rio de Janeiro: Jorge Zahar. (Trabalho original publicado em 1958).

Lacan, J. (2010). O Seminário livro 8: a transferência. 2. ed. Rio de Janeiro: Jorge Zahar. (Trabalho original publicado em 1960-1961).

Lacan, J. (1985). O Seminário livro 11: os quatro conceitos fundamentais da psicanálise. Rio de Janeiro: Jorge Zahar. (Trabalho original publicado em 1964).

Lacan, J. (1966-1967). O Seminário livro 14: La logique du fantasme. Inédito.

Lacan, J. (2009). O Seminário, livro 18: de um discurso que não fosse semblante. Rio de Janeiro: Jorge Zahar. (Trabalho original publicado em 1971).

Lacan, J. (2012). O Seminário, livro 19: ...ou pior. Rio de Janeiro: Jorge Zahar. (Trabalho original publicado em 1971-1972).

Lacan, J. (2008). O Seminário, livro 20: mais, ainda. Rio de Janeiro: Jorge Zahar. (Trabalho original publicado em 1972-1973).

Lacan, J. (1975). Conferência A terceira. Paris, inédito.

Lacan, J. (1976-1977). Le séminaire, livre XXIV: L'insu que sait de l'une-bévues'aile à mourre. Inédito.

Miller, J-A. (2010). Los divinos detalles. Buenos Aires: Paidós. (Trabalho original publicado em 1989).

Paz, O. (1994). A dupla Chama: Amor e Erotismo. Trad. Wladyr Dupont. São Paulo: Siciliano.

Platão. (1991). Diálogos: O Banquete - Fédon - Sofista - Político (Coleção os Pensadores). $5^{a}$ ed. São Paulo: Nova Cultural.

Schmidt, J. (1995). Dicionário de Mitologia Grega e Romana. Lisboa: Edições 70.

Citacão/Citation: Cruz Amaral, R.E.; Ribeiro Costa, C.A. (nov. 2018 a abr. 2019). Reflexões psicanalíticas sobre o amor a partir de Eros. Revista aSEPHallus de Orientação Lacaniana, 14(27), 5-25. Disponível em www.isepol.com/asephallus. Doi: 10.17852/1809-709x.2019v14n27p05-25

Editor do artigo: Tania Coelho dos Santos.

Recebido/Received: 03/08/2018 / 08/03/2018.

Aceito/Accepted: 12/10/2018 / 10/12/2018.

Copyright: (c) 2019 Associação Núcleo Sephora de Pesquisa sobre o moderno e o contemporâneo. Este é um artigo de livre acesso, que permite uso irrestrito, distribuição e reprodução em qualquer meio, desde que o autor e a fonte sejam citados/This is an open-access article, which permites unrestricted use, distribution, and reproduction in any medium, provided the author and source are credited. 